\title{
修正大血管転位症の診断
}

小山耕太郎
岩手医科大学医学部小児科学講座
岩手医科大学附属病院循環器医療センター循環器小児科
Key words:

congenitally corrected transposition of the great arteries, atrioventricular and ventriculoarterial discordance, sequential segmental analysis, right ventricular dysfunction, tricuspid regurgitation

\section{Diagnosis of Congenitally Corrected Transposition of the Great Arteries}

\author{
Kotaro Oyama \\ Department of Pediatrics, Iwate Medical University School of Medicine, Iwate, Japan \\ Division of Pediatric Cardiology, Iwate Medical University Memorial Heart Center, Iwate, Japan
}

Congenitally corrected transposition of the great arteries (CCTGA) is characterized by atrioventricular and ventriculoarterial discordance. Because of double discordance, the circulation is physiologically corrected, but the morphologic right ventricle supports systemic circulation, and $90 \%$ of patients have associated cardiac anomalies. The clinical presentation is influenced by the presence of associated anomalies. Since progressive systemic right ventricular failure and tricuspid regurgitation occur by the fourth decade in many patients with CCTGA, early intervention is recommended. The unique anatomy of CCTGA is malalignment between the atrial septum and the inlet part of the ventricular septum. This produces a gap into which is deeply wedged the pulmonary out flow tract and the abnormal course of atrioventricular conduction tissue. The aorta is usually anterior and to the left. Laboratory investigations including chest radiograph, electrocardiogram, echocardiography, MRI, and MDCT, reflect these morphological characteristics. Echocardiography is the imaging modality that provides the most accurate diagnostic assessment of CCTGA. It permits the identification of the basic anatomy by sequential segmental analysis as well as of associated anomalies. The role of echocardiography to evaluate the systemic right ventricular function is to be elucidated.

\section{要 旨}

本症は心房 -心室関係と心室-大血管関係の両方が正常の逆を示す疾患である．２段階の不一致によって血 液循環は生理学的に修正されるが, 約 $90 \%$ の例に合併病変がみられる。症状の出現時期は合併病変の種類と程 度によって胎児期から高齢者までさまざまであるが，加齢とともに体心室としての右室の機能低下や三尖弁閉 鎖不全，不整脈が認められるようになることから，早期の評価と治療介入が求められる．特有の解剖学的所見 として, 心房中隔と流入部心室中隔が整列しない, 左室流出路が僧帽弁と三尖弁の間に深く嵌り込む, 心房位が 正位の場合, 大動脈が肺動脈の左前方に位置する, 刺激伝導系が異常である等がある。これらの解剖学的特徵と 合併病変とを理解したうえで，診察と胸部 X 線，心電図，心エコー図，MRI，MDCT 等の検査を組み合わせて診 断する．特に心エコー図は区分診断法によって基本形態を明らかにするとともに合併病変の評価が可能であるこ とから本症の診断に最も大きな役割を担っている。 心エコー図による右室機能の定量評価が今後の課題である.

\section{1. 基本的事項の確認}

\section{1) 定義と疫学}

本症は心房 - 心室関係と心室 - 大血管関係の両方が 正常の逆を示す疾患である(atrioventricular と ventriculoarterial discordance. つまり 2 段階の不一致 double discordance がある). 右房は左室へ, 左房は右
室へつながり，左室からは肺動脈が，右室からは大動 脈が起始している。2 段階の不一致の結果, 合併病変 がなければ，静脈血は肺へ，動脈血は全身へと血液循 環は生理学的に修正されるが，実際には本症の約 90\%に合併病変がみられる。体循環を右室が担うこと から, 合併病変がなくとも, 加齢とともに右室機能低 下，三尖弁閉鎖不全が認められるようになる。心外病 
変の合併は少ない，頻度は全先天性心疾患の $1 \%$ 未満 と稀であり, やや男性に多い1,2).

\section{2)形態形成と成因}

原始心筒が正常とは反対に左側へループ形成 （1-loop）した結果，心室流入血流に異常が生じ，二次 的に円錐動脈幹中隔のらせん形成が障害されると考えら れているが詳細は不明である3 ${ }^{3}$. 同一家族内で修正大血 管転位症と完全大血管転位症が認められることがあり, Piacentini らの報告によると, 同胞における完全大血管 転位の再発率は $2.6 \%$, 先天性心疾患の再発率は $5.2 \%$ と高い ${ }^{4)}$. 体左右軸の決定に関与する複数の遺伝子の 変異が原因となっている可能性が示唆されている5 ${ }^{5}$.

\section{3) 解剖学的特徵}

本症を診断するうえで重要な解剖学的特徵は以下の通 りである，身体所見や画像所見はこれらの特徵を反映 している. (1)心房中隔と流入部心室中隔が整列しない (malalignment).このため, (2)左室流出路が僧帽弁と三 尖弁の間に深く嵌り込み(wedge), (3)刺激伝導路が異常 な走行を示す。心房位が正位の場合，(4)右側の僧帽弁は 肺動脈弁と線維性の連続性をもち, 左側の三尖弁と大動 脈弁との間には筋性の漏斗部が存在する。また, (5)動 脈が肺動脈の左前方に位置し, 両大血管は平行に走行す る. (6)冠動脈支配は $85 \%$ の例で正常の鏡像であり，右冠 動脈が体心室である右室を支配する。(7)区分診断は心房 位正位の $\{\mathrm{S}, \mathrm{L}, \mathrm{L}\}$ が約 95\%，心房位逆位の $\{\mathrm{I}, \mathrm{D}, \mathrm{D}\}$ が約 5\%である. 8执よそ90\%の例に合併病変が存在し, 心室中隔欠損 (60～ $80 \%$ ), 左室流出路 (肺動脈) 狭窄 (30 50\%), 三尖弁異常 (15 90\%) が特に多い ${ }^{1,2,6)}$.

\section{2. 症 状}

本症を診断する機会は胎児期から高齢者までさまざ まであるが，予後を改善するためには，合併病変を有 する例はもちろん, 大きな合併病変がない場合であっ ても, 加齢とともに右室機能不全や三尖弁閉鎖不全の進 行により心不全が出現するという自然歴を理解したうえ で，できるだけ早期に介入することが重要である7-9).

胎児エコーを用いたスクリーニングの普及によっ て, 出生前に本症と診断される例が増えており, 胎览 の房室ブロックを機に発見されることもある ${ }^{10)}$. 診断 時期としては新生児期が最も多く, 動脈管依存性を含 めチアノーゼを主訴とする場合が心不全によるよりも 多い，乳児期には心不全で診断される例が増え，チア ノーゼを呈する例とほぼ同じ割合である ${ }^{11)}$ ，年齢が高
くなるに従い，無症状ながら本症と診断される例が増 加する，わが国では学校心臓健診の心電図検査によっ て発見される例がある。

成人期には多くの例で心不全が進行する。ほぼ無症 状のまま高齢に達した，合併病変のない症例の報告も あるが，極めて例外的である。欧米における多施設か らの 182 例を後方視的に検討した研究によると，45 歳までに心不全を呈する割合は，合併病変を有する場 合 $67 \%$, 合併病変がない場合 $25 \%$ である7)。心不全 の主たる原因は右室機能不全と三尖弁閉鎖不全である が，両者の関連は必ずしも明らかでない，しかし，右 室機能不全が進行する以前に三尖弁置換をすることが 予後の改善につながると考えられている ${ }^{12,13)}$. また, 心筋シンチによる検討では右冠動脈が支配する右室心 筋の灌流障害が示されており，不十分な冠循環が右室 機能不全の原因の 1 つである可能性がある ${ }^{14)}$. 房室ブ ロックの出現頻度は, 平均 22 年間追跡したHuhta ら の報告によると年平均 $2 \%$ であり，心室中隔欠損や三 尖弁の手術後に多くみられる ${ }^{15)}$ ，加齢に伴い上室性頻 拍，心房粗動，心房細動などの頻脈性不整脈もみられ るようになる。

\section{3. 身体所見}

診察では本症の解剖学的特徵に基づく所見と合併病 変による所見とを合わせてとらえる必要があるが，合 併病変がない場合, 診察所見はしばしば正常と区別が つかない. 大動脈が肺動脈の左前方に位置し胸壁に近 いことから，年長児や成人では 2 音が単一で充進して 聴かれ, 肺高血圧を疑われて診断にいたることがある. 成人では 2 音を触知する場合もある。心室中隔が胸骨 の裏にほほ垂直に位置し, 左右心室は横に並ぶことか ら，特に成人では心尖拍動を正常に比べ内側寄りの胸 骨左縁に認める。心室中隔欠損と三尖弁閉鎖不全の沉 収縮期雑音は胸骨左縁で聴かれる。本症に伴う Ebstein 氏病では通常三尖弁前尖は大きくなく，いわ ゆる sail sound は聴かれない ${ }^{13)}$. 肺動脈狭窄による駆 出性雑音は右上方へ放散する。大きな心室中隔欠損や 重度の三尖弁閉鎖不全を伴う例では呼吸困難や易疲労 性などの心不全徵候がみられる。心室中隔欠損に肺動 脈狭乍ないし閉鎖を伴う例では新生児期にチアノーゼ を呈する，完全房室ブロックでは徐脈と頸静脈波に巨 大 a 波 (cannon wave)を認める. 


\section{4. 胸部 X線}

左第 1 ～ 3 弓は上行大動脈が形成し，なだらかにな る. 左第 4 弓は右室が形成し, 丸みを带びることから, 心院影はボーリングのピンに似る ${ }^{16,17)}$. 本症の 20 30\%は右胸心であり，15\%は中心症 (mesocardia)であ る $^{18)}$ (Fig. 1)。内臟心房位正位で右胸心, 中心症があ ればまず本症を考える。逆位は $5 \%$ にみられる。

肺血管陰影と心胸比は合併病変に応じた所見を呈す る. 大きな心室中隔欠損では肺血管陰影の増強と心拡 大がみられ，心室中隔欠損に肺動脈狭窄ないし閉鎖を 伴う例では肺血管陰影は減弱し, 心院影は小さい。 三 尖弁閉鎖不全では心拡大と肺門理の増強がみられる。

\section{5. 心電図所見}

心電図所見には(1)心室逆位に基づく QRS パターン の変化と(2)心臟の位置による変化, (3)右側心室負荷に よる変化，(4)不整脈がある，Q波は心室中隔の興奮過 程を表し, 左室側から右室側へ伝播するので, 解剖学 的左室が存在する誘導にQ 波がみられる，合併病変 のない本症では初期ベクトルは左前上方へ向かい, 右 側胸部誘導の $\mathrm{Q}$ 波, III誘導・aVF 誘導の深い $\mathrm{Q}$ 波と 左側胸部誘導・I 誘導· $\mathrm{aVL}$ 誘導に㧍ける Q 波の欠如, 左軸偏位がみられる(Fig. 2)。これらの所見は特に年 長児で明暸である。ときに下壁梗塞と誤られる場合も ある。室中隔欠損と肺動脈狭窄を伴うと QRS 電気 軸は正常ないし右軸偏位, V1で qRパターン, V6 で $\mathrm{rS}$ パターンを呈す。胎児期から完全房室ブロックが

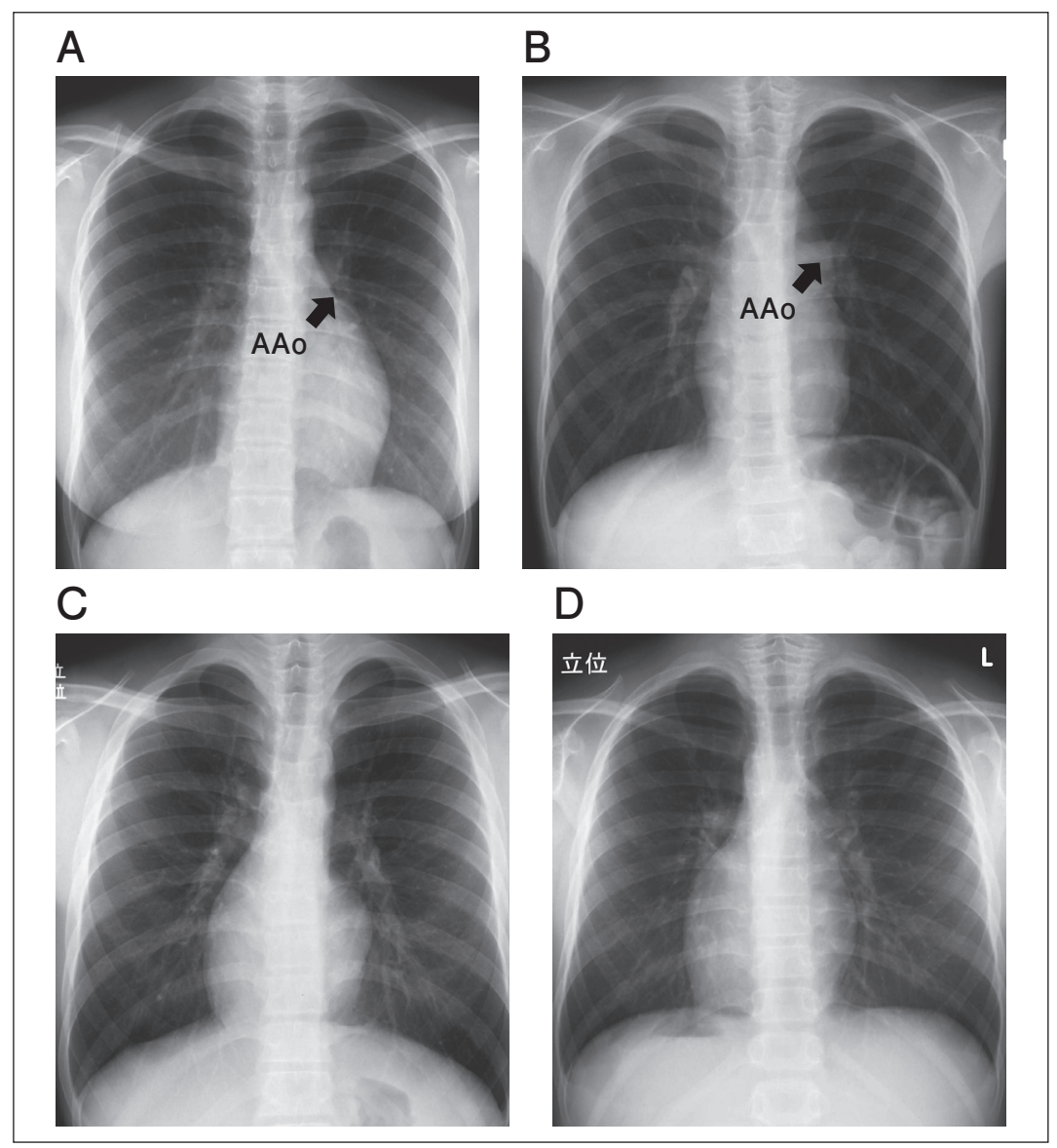

Fig. 1 修正大血管転位症の胸部 X 線写真

$\{S, L, L\}$ 修正大血管転位症では, 左第 $1 \sim 3$ 弓は上行大動脈（AAo）が 形成し，なだらかになる (矢印)。左第 4 弓は右室が形成し，丸みを帯びる ことから心陰影はボーリングのピンに似る $(\mathrm{A})$. 中心症 (mesocardia) は $15 \%$ にられる(B).

内臓心房位正位で右胸心があればまず $\{\mathrm{S}, \mathrm{L}, \mathrm{L}\}$ 修正大血管転位症を考 える (C). 内臟心房位逆位 $\{1, D, D\}$ は本症の $5 \%$ にみられる (D). 


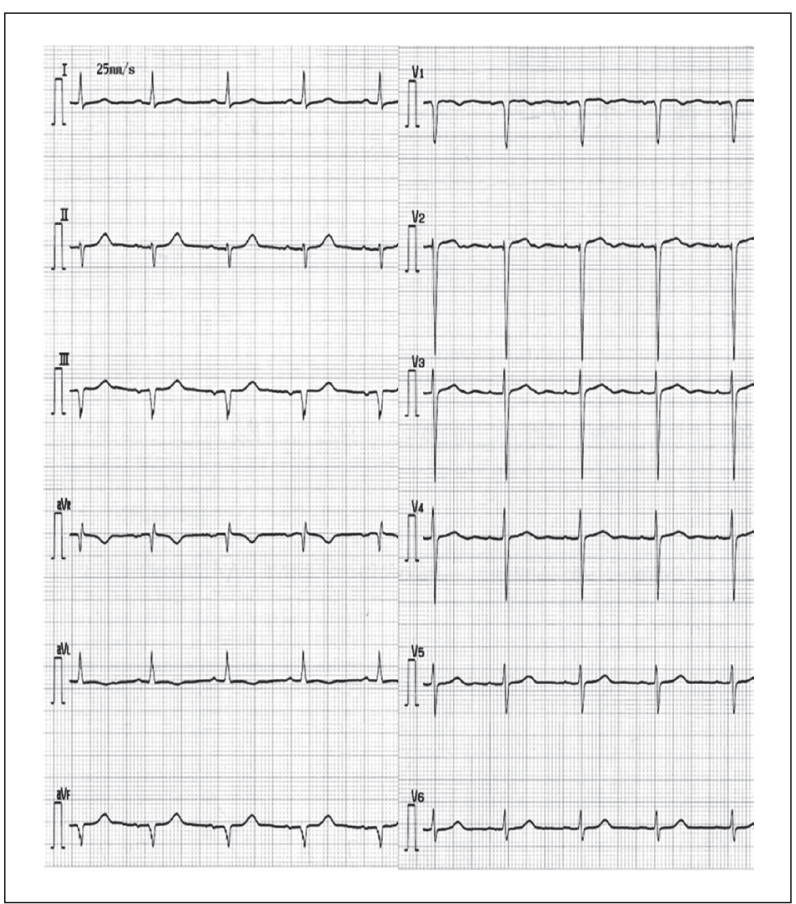

Fig. 218 歳, 女性の心電図

合併病変のない $\{S, L, L\}$ 修正大血管転位症, 左胸心. 右側胸部誘導と而誘導, aVF 誘導の深い $Q$ 波, 左側 胸部誘導と I 誘導, $\mathrm{aVL}$ 誘導の $\mathrm{Q}$ 波の欠如, 左軸偏 位がみられる。

みられる例や生後に房室ブロックが進行する例があ る. WPW 症候群の合併が数\%にみられる。成人では 心房粗動，心房細動もみられる

\section{6. 心エコー図}

1) 区分診断法による診断

心エコー図は本症を診断するうえで最も大きな役割 を担っている。分診断法によって atrioventricular and ventriculoarterial discordance を診断する。診断には 剣状突起下からと心尖部からの断面が特に有用であ る。它房位を決定するうえで最も簡便で確実なのは下 大静脈の流入する心房が解剖学的右房と判断する方法 である。また，心房中隔面をみて厚い二次中隔を有す る心房が解剖学的右房であり，薄い一次中隔のあるほ うが解剖学的左房である ${ }^{19,20)}$. 左右心耳の特徵的な形 態を心エコーで判断することは困難なことが多い。心 室位の診断では, 解剖学的右室は中隔帯 moderator band を有するのが特徵であり, 中隔面は粗な肉柱か らなり, 自由壁の肉柱形態も粗い. 房室弁の付着位置 が解剖学的左室に比べ心尖寄りであり, 腱索は心室中 隔に付着する, 一方, 解剖学的左室は心室中隔面の肉 柱が細かく, 房室弁は 2 個の乳頭筋が自由壁に付着す

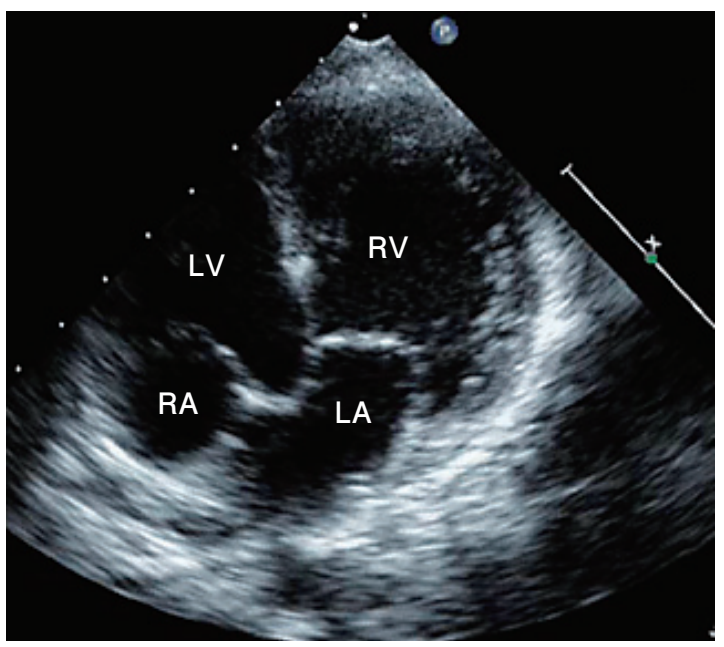

Fig. 3 心尖部四腔断面像

心房中隔と流入部心室中隔は整列せず (malalignment), 四腔断面が描出しにくい. $\mathrm{RV}$ : 右室, $\mathrm{LV}$ : 左室, LA : 左房, RA：右房

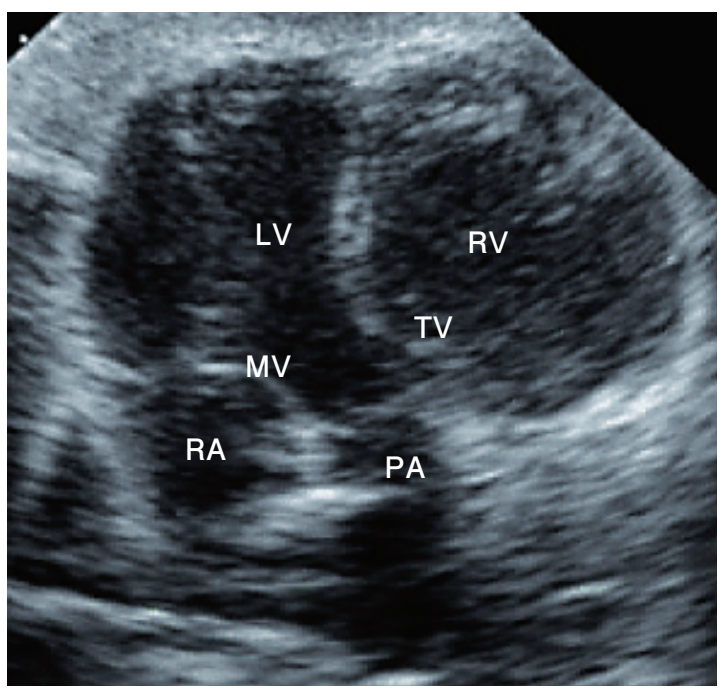

Fig. 4 心尖部左室長軸像

左室流出路・肺動脈が左右の房室弁の間に深く 嵌り込んでいる。

RV：右室, TV：三尖弁, LV：左室, MV：僧 帽弁, PA：肺動脈, RA：右房

る，大血管位の診断は，大動脈は心室から起始した後 は分岐することなく上行し，大動脈弓を形成して頸部 血管を分枝すること, 肺動脈は心室から起始してすぐ 左右の肺動脈に分岐することによって行う，冠動脈は 肺動脈からの起始異常があるため，大動脈の同定には 必ずしも正しく用いることができない ${ }^{19}$,20). まず心房 位，心室位，大血管位を決め，次に心房一心室関係， 心室 -大血管関係を決定し, 2 段階の不一致 double discordanceの存在を示す. 本症では大動脈と肺動脈は, 正常のらせん状の交差とは異なり, 平行に走行する。 


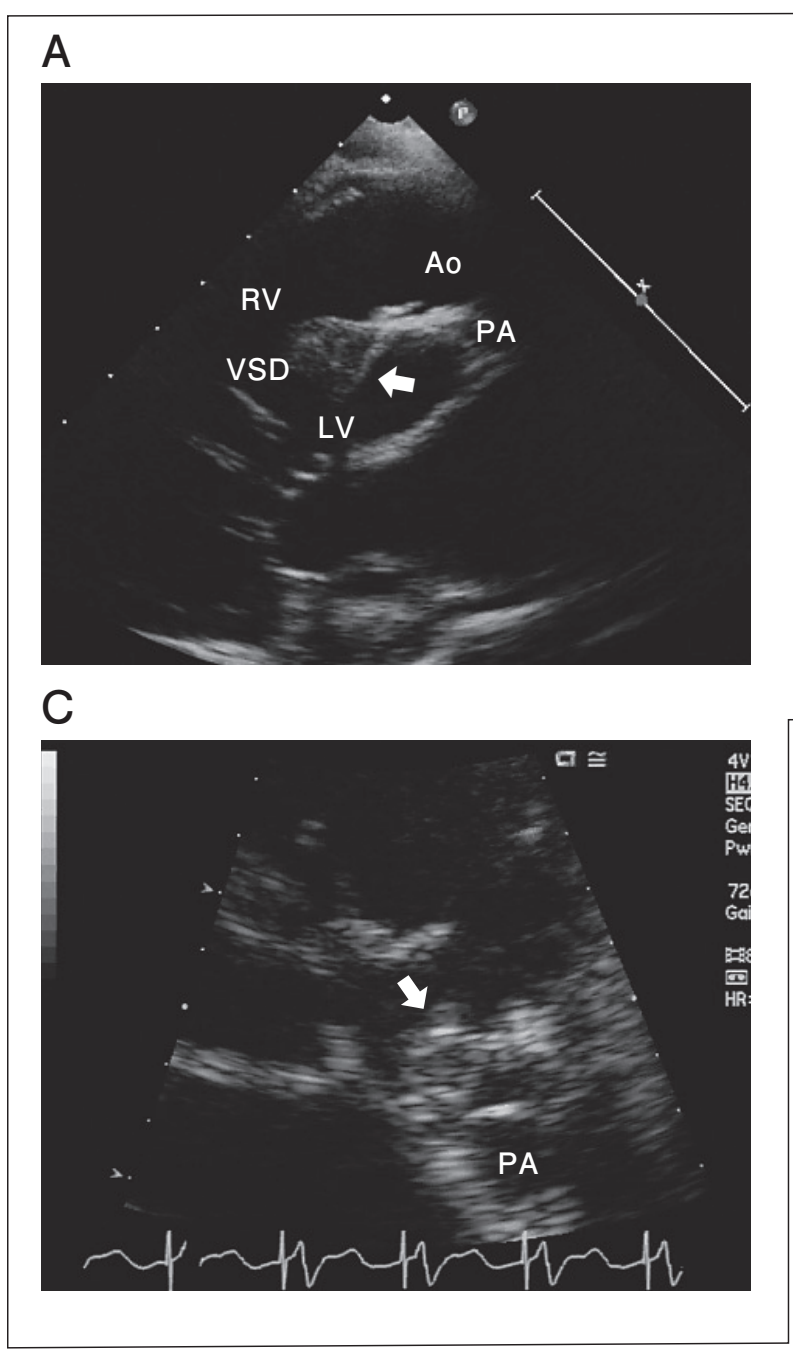

心エコー図上注意すべき点として，心房中隔と流入 部心室中隔が整列せず(malalignment), 四腔断面が描 出しにくいこと (Fig. 3), 正常では大動脈弁が僧帽弁と 三尖弁の間に嵌まり込んでいる(wedge)のに対し，本 症では左室流出路・肺動脈が左右の房室弁の間に奥深 く嵌り込んでいて狭窄性病変を伴いやすいことがあげら れる (Fig. 4). 右胸心や中心症が多い点も注意を要す る. 三尖弁の短軸像を明瞭に描出するには肋間を高くす る, 超音波の入射角を変えるなどの調整が必要である.

\section{2) 合併病変の診断}

心室中隔欠損は膜様部欠損が多く，多くの場合，流 入路や心尖部に進展しているが, 筋性部欠損, 流出路 両半月弁下欠損もあり得る. 左室流出路一肺動脈狭窄 は心室中隔欠損に伴ってみられることが多く, 主体は 弁下狭窄であり, 心室中隔と左室自由壁による筋性狭 窄をはじめ, 線維筋性組織や膜様部中隔㽷, 僧帽弁 · 三尖弁副組織による狭窄などがある。これらに弁性狭

\section{B}

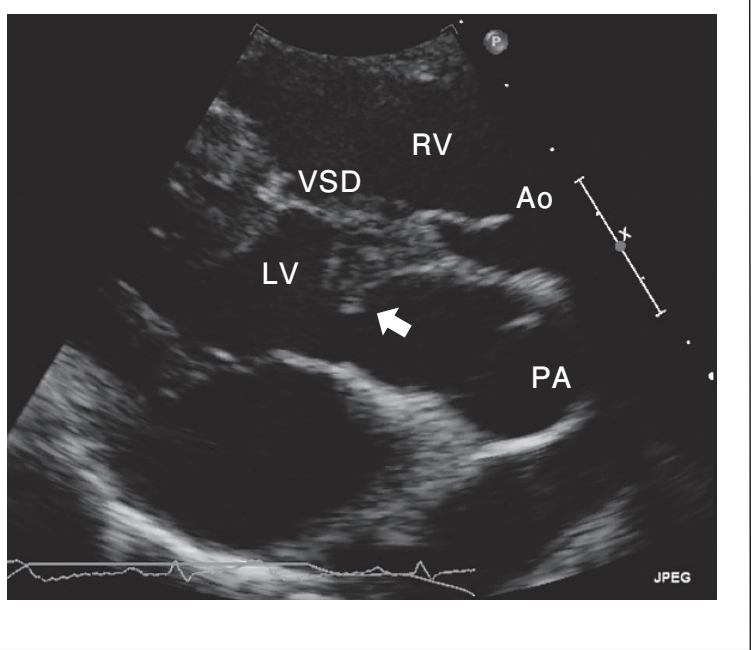

Fig. 5 胸骨左縁左室長軸像
A：筋性狭窄による弁下狭窄（矢印）と弁性狭 窄の合併。
B：線維笳性狭寉による弁下狭窄（矢印）と弁 性狭窄の合併.
C：僧帽弁副組織 accessory mitral tissue（矢

印）による弁下狭窄と弁性狭窄の合併。

Ao : 大動脈, $\mathrm{RV}$ ：右室, $\mathrm{PA}$ ：肺動脈,

$\mathrm{LV}$ : 左室, VSD : 心室中隔欠損

窄を伴うことも多い(Fig. 5).

三尖弁異常は多くは心室中隔欠損に伴ってみられ る。異形成弁や Ebstein 氏病の他に, straddling や overriding, double orifice などがある。本症に伴う Ebstein 氏病では三尖弁の下方付着はあるが，通常の Ebstein 氏病とは異なり，帆のように大きな前尖はみ られない。また中隔尖や後尖の心室中隔への癒着は軽 く，心房化心室も目立たない(Fig. 6). 三尖弁逆流の 定量評価は通常の僧帽弁逆流の定量評価に準じて試み られる ${ }^{21)}$ ，逆流面積， vena contracta の径，加速血流 acceleration flow, proximal isovelocity surface area (PISA) から逆流量, 逆流率, 有効逆流弁口面積を測定する.

本症の合併病変である心室中隔欠損と三尖弁閉鎖不全 は, 体心室である右室に容量負荷をもたらし, 右室拡大, 三尖弁輪の拡大からさらに三尖弁逆流を増悪させ，右 室機能を低下させる。一方, 肺動脈絞扼術後には三尖 弁逆流が軽減することが観察される。肺動脈絞扼術によ る左室圧の上昇によって心室中隔が右室側に偏位して, 三尖弁の機能を改善させるためと考えられている1 ${ }^{1}$. 肺動脈絞扼術や左室流出路・肺動脈狭窄は三尖弁閉鎖 不全に対して防御的に作用するといえる(Fig. 7).

\section{3)体心室としての右室機能の評価の試み}

複雑な形態を有する右室の機能評価の検討は左室の 
それに比べ十分でなかったが，最近心エコー図による 右室機能評価についてのガイドラインが提案された222. これはあくまでも成人における肺循環心室としての右 室機能評価であるが，二次元断層法による右室 fractional area change(FAC) (正常：35\%以上) (Fig. 8), 三尖弁輪の収縮期移動距離 tricuspid annular plane systolic excursion(TAPSE) (正常：16 $\mathrm{mm}$ 以上), 組織 ドプラ法による三尖弁輪の $\mathrm{S}^{\prime}$ (正常 : $10 \mathrm{~cm} / \mathrm{s}$ 以上), そして Tei index(正常：パルスドプラ法で 0.4 未満, 組織ドプラ法で 0.55 未満)の測定が右室収縮機能の評
価として推奨されている．右室容量の計測は二次元法 に比べ三次元エコーのほうがより正確であるが，正常 值に関するデータの蓄積はいまだ十分でない.

体心室としての右室機能は正常の右室に比較し長軸方 向の strain が低下寸る一方, 円周方向の strain が高值を 示すことや左室にみられる torsion が右室では観察され ないこと等が報告されているが，本症を対象とした評価 は限られている ${ }^{23-27)}$ 。心エコー図は本症の右室機能不 全に対する心臓再同期療法の評価にも有用である 26,27$)$.

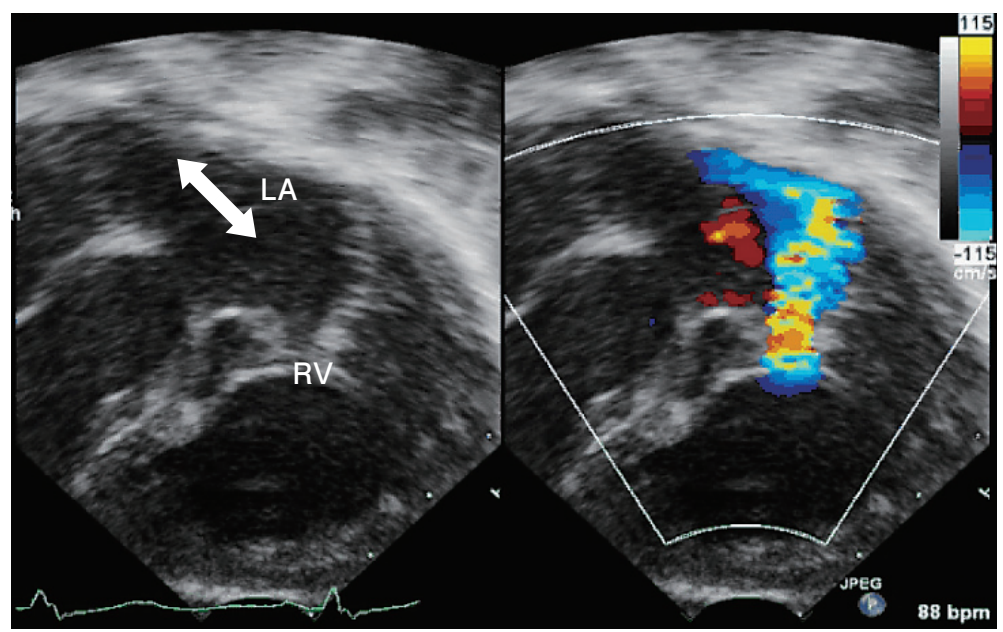

Fig. 6 心尖部四腔断面像

Ebstein 氏病に伴う重度の三尖弁逆流. 三尖弁中隔尖は大きく plasteringしている(矢印)。本症では通常の Ebstein 氏病にみられ るような大きな前尖は少ない. 中隔尖や後尖の心室中隔への癒着は軽 く, 心房化心室も目立たない.

$\mathrm{RV}$ : 右室, LA : 左房

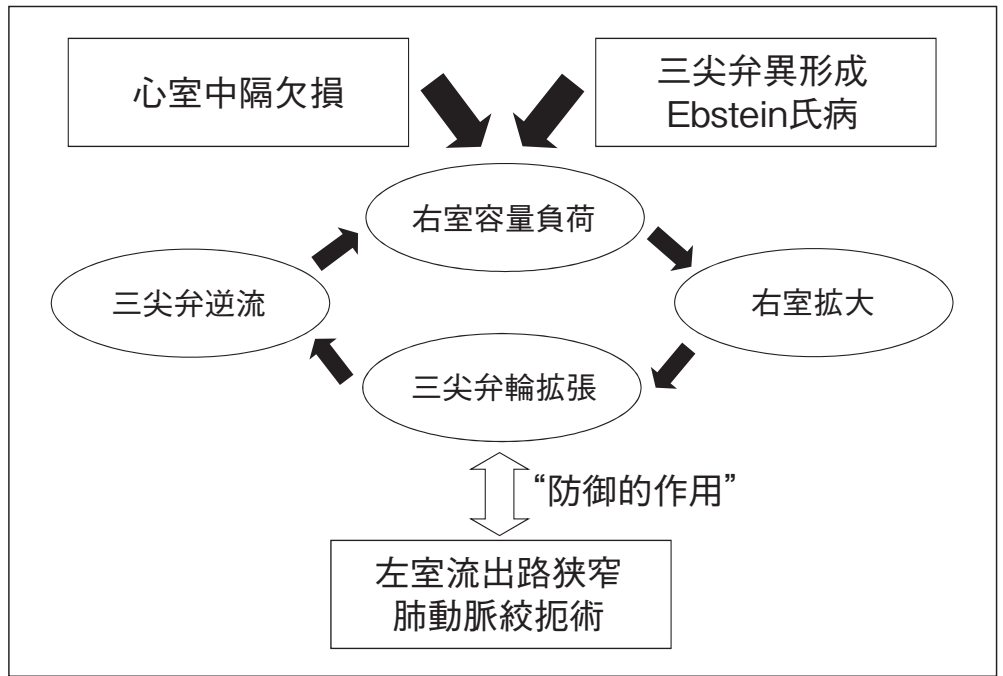

Fig. 7 体心室としての右室の機能不全の悪循環

心室中隔欠損の左右短絡と三尖弁閉鎖不全とが右室の容量負荷をもた らし, 体心室としての右室の機能不全に悪循環が形成される.これに 対して肺動脈絞扼術や左室流出路狭窄は防御的に働く. 


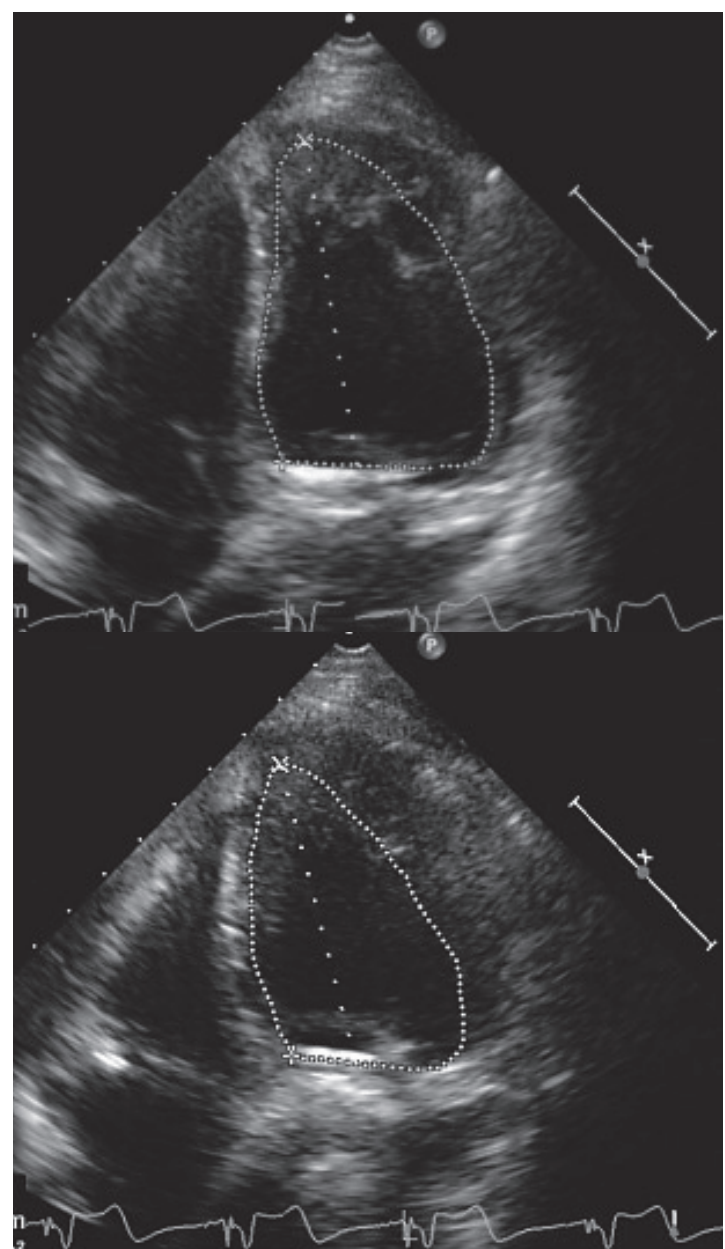

Fig. 8 心尖部四腔断面像

$\{S, L, L\}$ 修正大血管転位症, 三尖弁置換術後, 心臓再同期療法の患者における右室 fractional area change (FAC) の測定.

\section{7. $\mathrm{MRI} \cdot \mathrm{MDCT}$}

音響空の制限から心エコー図による形態評価が困難 な場合には，MRIによる左右心室の同定や合併病変 の診断が有用である。また右室機能評価についてみる と, 二次元心エコー図で複雑な形態の右室の全体像を 評価することが困難なことから，MRI が gold standard と考えられている ${ }^{28,29)}$ 。しかし，MRIによる容量計測 においても，右室の短軸に沿うか，長軸に沿うかで值 が異なることや体心室として肥大した右室壁の肉柱が 計測を困難にすることなどの課題がある ${ }^{30,31)}$

MDCT は高い空間分解能を有することから, 複雑 な先天性心疾患の大動脈や冠動脈の評価に優れてい る。われわれは狭小な心室中隔欠損と肺動脈狭窄を有 し, aortic translocation 法が適応となる例について, 320 列 MDCT を併用し, 大動脈と冠動脈, 左室流出路,

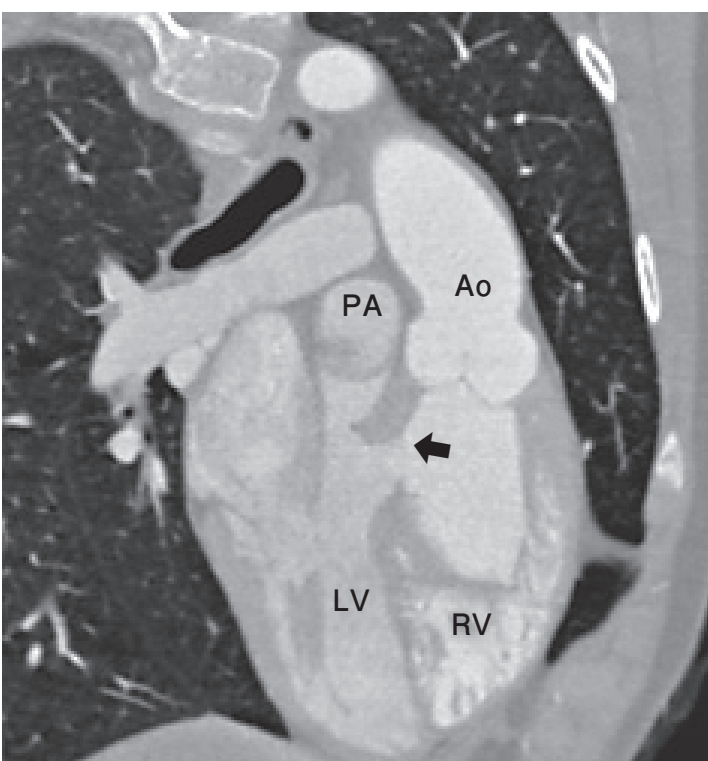

Fig. 9320 列 MDCT 像

本例は狭小な心室中隔欠損（矢印）と肺動脈狭 窄を有するため, aortic translocation 法の適応 となる。大動脈と肺動脈, 左室流出路, 心室中 隔欠損の関係を三次元的に評価する.

$\mathrm{RV}$ ：右室, $\mathrm{LV}$ ：左室, Ao：大動脈, PA：肺動脈

肺動脈，心室中隔欠損の関係を三次元的に評価してい る $^{32)}$ (Fig. 9).

\section{8. 心臓カテーテル法}

本症の診断にカテーテル法が必要になることは少な く, 多くは肺血管抵抗や左右短絡, 左室流出路狭窄の 定量評価に用いられる。房室伝導路が心室中隔欠損の 前上方を通過するため, 肺動脈へカテーテルを進める 際に房室ブロックをきたしやすい.

\section{【参考文献】}

1) Graham TP Jr: Congenitally corrected transposition. in Gatzoulis MA, Webb GD, Daubeney PEF (ed): Diagnosis and management of adult congenital heart disease. Edinburgh, Churchill Livingstone, 2003, pp379-387

2) Dick JD, Atallah J: Congenitally corrected transposition of the great arteries. in Allen HD, Driscoll DJ, Shaddy RE, Feltes TF (ed): Moss and Adams' Heart disease in infants, children, and adolescents including the fetus and young adult. $7^{\text {th }}$ ed. Philadelphia, Lippincott Williams \& Wilkins, 2008, Vol 2, pp1087-1100 
3)白石 公:心臓のルーピング. 白石 公, 山岸敬幸 (編): 先天性心疾患を理解するための臨床心臓発生学。東京, メジカルビュー社, 2007, pp85-90

4) Piacentini, G, Digilio MC, Capolino R, et al: Familial recurrence of heart defects in subjects with congenitally corrected transposition of the great arteries. Am J Med Genet 2005; 137A: 176-180

5) De Luca A, Sarkozy A, Consoli F, et al: Familial transposition of the great arteries caused by multiple mutations in laterality genes. Heart 2010; 96: 673-677

6) Brawn, WJ, Jones TJJ, Anderson RH, Barron DJ: Congenitally corrected transposition. in Aderson RH, Baker EJ, Penny DJ, Redington AN, Rigby ML, Wernovsky G (ed): Pediaric Cardiology $3^{\text {rd }}$ ed. Philadelphia, Churchill Livingstone, 2010, pp819-835

7) Graham TP, Bernard YD, Mellen BG, et al: Long-term outcome in congenitally corrected transposition of the great arteries. J Am Coll Cardiol 2000; 36: 255-261

8) Metton O, Gaudin R, Ou P, et al: Early prophylactic pulmonary artery banding in isolated congenitally corrected transposition of the great arteries. Eur J Cardiothorac Surg 2010; 38: 728-734

9) Hraska V, Mattes A, Haun C, et al: Functional outcome of anatomic correction of corrected transposition of the great arteries. Eur J Cardiothorac Surg 2011; 40: 1227-1235

10) Sharland G, Tingay R, Jones A, et al: Atrioventricular and ventriculoarterial discordance (congenitally corrected transposition of the great arteries): echocardiographic features, associations, and outcome in 34 fetuses. Heart 2005; 91: 1453-1458

11) Rutledge JM, Nihill MR, Fraser CD, et al: Outcome of 121 patients with congenitally corrected transposition of the great arteries. Pediatr Cardiol 2002; 23: 137-145

12) Lundstrom U, Bull C, Wyse RKH, et al: The nature and "unnatural" history of congenitally corrected transposition. Am J Cardiol 1990; 65: 1222-1229

13) Warnes CA: Transposition of the great arteries. Circulation 2006; 114: 2699-2709

14) Hornung TS, Bernard EJ, Jaeggi ET, et al: Myocardial perfusion defects and associated systemic ventricular dysfunction in congenitally corrected transposition of the great arteries. Heart 1998; 80: 322-326

15) Huhta JC, Maloney JD, Ritter DG, et al: Complete atrioventricular block in patients with atrioventricular discordance. Circulation 1987; 67: 1374-1377

16)中澤 誠：修正大血管転換。中澤 誠(編)：新目でみる 循環器病シリーズ 13 先天性心疾患. メジカルビュー社, 東京, 2005, pp252-259

17）門間和夫：修正大血管転換, 高尾篤良, 門間和夫, 中澤 誠, 中西敏雄 (編): 臨床発達心臓病学 第 3 版. 中外医学 社, 東京, 2001, pp528-533

18) Maldjian PD, Saric M: Approach to dextrocardia in adults: review. AJR 2007; 188: S39-S49

19) Gillis E, Springer R, O'Leary PW: Practical issues related to the examination, anatomic image orientation, and segmental cardiovascular analysis. in Eiden BW, Cetta F, O'Leary PW (ed): Echocardiography in pediatric and adult congenital heart disease. Philadelphia, Lippincott Williams \& Wilkins, 2010 , pp10-28

20) 瀧聞浄宏:古くてあたらしい区分診断法. 石井正浩(編): 第 3 回日本小児循環器学会教育セミナーテキスト 躍動 する小児心エコー図法. 2011, pp42-45

21) Earing MG, Ayres NA, Cetta F: Congenitally corrected transposition of the great arteries. in Eiden BW, Cetta F, O' Leary PW (ed): Echocardiography in pediatric and adult congenital heart disease. Philadelphia, Lippincott Williams \& Wilkins. 2010, pp145-157

22) Rudski LG, Lai WW, Afilalo J, et al: Guidelines for echocardiographic assessment of the right heart in adults: a report from the American society of echocardiography. J Am Soc Echocardiogr 2010; 23: 685-713

23) Petterson E, Helle-Valle T, Edvardsen T, et al: Contraction pattern of the systemic right ventricle. J Am Coll Cardiol 2007; 49: 2450-2456

24) Chow P-C, Liang X-C, Cheung EWY, et al: New twodimensional global longitudinal strain and strain rate imaging for assessment of systemic right ventricular function. Heart 2008; 94: 855-859

25) Eidem BW, O'Leary PW, Tei C, et al: Usefulness of the myocardial performance index for assessing right ventricular function in congenital heart disease. Am J Cardiol 2000; 86: 654-658

26）高橋 信, 小山耕太郎, 籏 義仁, 他 : 修正大血管転位 症に合併した重症心不全に対する心臓再同期と三尖弁 置換の併用療法. 日児誌 2007; 111: 1066-1071

27) Jauvert G, Rousseau-Paziaud J, Villain E, et al: Effect of cardiac resynchronization therapy on echocardiographic indices, functional capacity, and clinical outcomes of patients with a systemic ventricle. Europace 2009; 11: 184-190

28) Warnes CA, Williams RG, Bashore TM, et al: ACC/AHA 2008 guidelines for the management of adults with congenial heart disease. J Am Coll Cardiol published online Nov 14, 2008.

29) Kilner PJ, Geva T, Kaemmerer H, et al: Recommendations for cardiovascular magnetic resonance in adults with congenital heart disease from the respective working groups of the European Society of Cardiology. Eur Heart J 2010; 31: 794 805

30) Grewal J, Majdalany D, Syed I, et al: Three-dimensional echocardiographic assessment of right ventricular volume and function in adult patients with congenital heart disease: comparison with magnetic resonance imaging. J Am Soc echocardiogr 2010; 23: 127-133

31) Winter MM, Bernink FJP, Groenink M, et al: Evaluating the systemic right ventricle by CMR: the importance of consistence and reproducible delineation of the cavity. J Cardiovasc Magn Reson 2008: 40-47

32) 小山耕太郎, 吉岡邦浩：大動脈奇形。陣崎雅弘(編)：心 CT 先天性心疾患の MDCT. 文光堂, 東京, 2010, pp8491 